\title{
TECHNOLOGICAL ASPECTS OF THE ROBOTIC TOPTIG SURFACING OF BOILER STEEL TUBES USING ALLOY INCONEL 625
}

\author{
T. PFEIFER ${ }^{1}$, M. RÓŻAŃSKI ${ }^{1}$, W. GROBOSZ ${ }^{1}$, J. RYKALA ${ }^{1}$, I.A. RIABCEW ${ }^{2}$ \\ ${ }^{1}$ Instytut Spawalnictwa w Gliwicach, Poland, 44-100. Gliwice, ul. Bl. Czeslawa 16-18. E-mail: is@is.gliwice.pl \\ ${ }^{2}$ E. O. Paton Electric Welding Institute NASY. 11 Kazimir Malevich Str., 03680, Kyiv, Ukraine. E-mail: journal@paton.kiev.ua
}

\begin{abstract}
The research aimed to develop technological parameters of the TOPTIG method-based surfacing (using alloy Inconel 625) of boiler tubes $(\varnothing 45 \times 5)$ made of steel 13CrMo4-5 ensuring the obtainment of the iron content on the overlay weld surface below $5 \%$. The research resulted in the development of sets of parameters enabling the obtainment of overlay welds characterised by very high quality and the minimum degree of the stirring of the overlay weld metal with the base material. The above named sets of parameters were utilised when making a number of overlay welds on tubes. The research involved macroscopic metallographic tests of overlay welds, the identification of the base material content in the overlay weld, the determination of the chemical composition of the overlay weld surface as well as the performance of microscopic metallographic tests and the microanalysis of the chemical composition. It was ascertained that the TOPTIG technology enabled the making of overlay welds characterised by very high quality and the minimum degree of the stirring of the overlay weld metal with the base material (only $3.28 \%$ ) and made it possible to obtain an iron content of $2.75 \%$ on the overlay weld surface using forced cooling performed inside the tube. Surfacing without cooling led to a significantly higher base material content in the overlay weld (approximately $14 \%$ ), where the content of iron on the overlay weld surface amounted to $8.47 \%$. References 13. Tabl. 3. Fig. 8.
\end{abstract}

Key words : robotic surfacing, TOPTIG method, alloy Inconel 625, boiler tubes, waste incineration boilers, Fe content on the overlay weld surface

\section{Introduction}

Power plants fed with fossil fuels and waste incineration plants used for power generation must satisfy strict requirements as regards power boiler components including furnaces, collectors, superheaters and pipings. The above-named requirements result from extreme working conditions of components exposed to abrasion and erosion. The incineration of waste in boilers results in the formation of flue gas containing aggressive chlorides and fluorides, the detrimental effect of which requires the use of appropriately effective protections from erosion and corrosion of e.g. tubes of heat exchangers and combustion chambers. Presently, the service life of such elements is increased by the surfacing of layers of nickel alloys, particularly having the composition of alloy Inconel 625, providing appropriate creep resistance at high temperature and corrosion resistance in the aggressive environment of fluorides and chlorides. Presently used surfacing methods include gas-shielded metal arc surfacing (using pulsed current and the low-energy CMT method), plasma-powder surfacing, laser surfacing and non-consumable electrode inert gas surfacing (TIG) [1-13].

One of the primary criteria to be satisfied by a surfaced coating is low iron content (maximum $5 \%$ in the external zone), a thickness not exceeding $2.0 \div 2.5 \mathrm{~mm}$ as well as the lack of the microsegregation of alloying elements in the overlay weld. Iron content higher than that mentioned above reduces corrosion resistance, whereas an excessive thickness increases both the weight of structures and the costs of surfacing processes. In turn, the microsegregations of elements, particularly $\mathrm{Nb}$ and Mo, cause the formation of intermetallic phases decreasing the corrosion resistance of overlay welds $[2,3,7,8]$.

Technical reference publications contain information concerning the structure and properties of overlay welds made using gas-shielded metal arc surfacing, including the low-energy variant of CMT method [1-3]. The presented results indicate that, when welding using arc methods, the satisfaction of the above-presented requirements needs the making of a minimum of 2 layers, which extends the operating time and could lead to the formation of excessive stresses and strains of surfaced elements (length of surfaced tubes up to $12 \mathrm{~m}$ ). The tests described in publication [1] revealed that it was not possible to entirely eliminate the microsegregation of alloy components reducing the service life of the layers. It was ascertained that as a result of microsegregation occurring during the solidification of overlay welds, the cores of dendrites were richer in $\mathrm{Ni}, \mathrm{Fe}$ and $\mathrm{Cr}$, whereas the interdendritic areas were richer in Mo and $\mathrm{Nb}$. During the solidification, the strongest segregation was that of niobium, 
less intense was that of molybdenum, whereas the segregation of chromium was the least intense. Individual research revealed that similar results were obtained using plasma-powder surfacing [10-13]. It appears that surfacing utilising the CMT and plasmapowder methods could be alternatively replaced by TIG surfacing: plasma surfacing with wire feeding and the surfacing utilising an innovative TIG method, i.e. TOPTIG (feeding the wire at an angle of approximately $20^{\circ}$ in relation to the electrode), where the wire is fed either in a continuous or in a pulsed manner. This article presents the course and selected results of tests aimed at the determination of the effect of TOPTIG surfacing on the structure of overlay welds made of nickel alloy Inconel 625 applied on the base made of steel 13CrMo4-5.

\section{Materials, Test Rig and Testing Methodology}

The base material used in the tests had the form of seamless tubes $(\varnothing 45 \times 5.0 \mathrm{~mm})$ made of steel 13CrMo4-5 according to PN-EN 10216-2:201402 (15XM according to GOST4543-71). The technological tests involved the use of an OK Autrod NiCrMo-3 solid wire (Inconel 625) having a diameter of $1.0 \mathrm{~mm}$ (ESAB).

The technological tests of the surfacing process were performed using a station equipped with a ROMAT 310 robot (Cloos) and a TOPTIG 220DC machine (Air Liquide Welding).

The technological tests were initiated by the performance of a number of surfacing tests (simple overlay welds made on sheets) using various process parameters and aimed to identify the effect of basic current, impulse current and of a filler metal wire feeding rate on the quality, geometry and uniformity of overlay welds as well as on penetration depth. More than 60 various sets of parameters were tested. The further stage of research-related tests concerned with surfacing performed on tubes made of steel 13CrMo4-5 involved the use of parameters ensuring the obtainment of the highest quality and the lowest degree of the stirring of the overlay weld with the base. The most favourable parameters are presented in Table 1. The overlay welds were made on the tubes without cooling performed inside the tubes (items 1-6 Table 1). For comparative purposes, overlay welds were also made with the forced cooling performed inside the tube, where the cooling medium was water (items 7 and 8, Table 1).

After the overlay welds were made on the tubes, the latter were subjected to macroscopic metallographic tests and measurements enabling the calculation of the base material content in the overlay welds. The macroscopic metallographic photographs were used to determine the cross-sectional areas of excess overlay weld metal and of the partially melted base material as well as to identify the overlay weld height $(W)$, penetration depth $(G)$ and the base material content in the overlay weld. The abovenamed parameter was determined as the proportion of the area of penetration in the material to the area of the entire overlay weld. The overlay weld geometry measurements were performed using the Autodesk Inventor Professional 2016 software programme. The measurement results are presented in Table 2 .

The subsequent stage of research involved the analysis of chemical composition of the overlay weld surface aimed to determine the content of iron as well as to measure hardness in the surfaced layer and in the HAZ. The analysis of the chemical composition was performed using spark source optical emission spectrometry and Q4 TASMAN spectrometer (Bruker). The hardness measurements (Vickers hardness test) were performed on the cross-sections of the overlay welds using a KB50BYZ-FA hardness tester (KB Prütechnik GmbH) and a load of $H V 10$.

The next stage involved microscopic metallographic tests, the microanalysis of the cross-sectional chemical composition and the determination of the surface distribution of chemical elements. The metallographic specimens were prepared by grinding utilising $\mathrm{SiC}$ papers having a granularity of 280-1200 followed by polishing involving the use of diamond pastes ( 3 and $1 \mu \mathrm{m})$ and etching $\left(3 \mathrm{~g} \mathrm{FeCl}_{3}, 10 \mathrm{ml} \mathrm{HCl}\right.$, $90 \mathrm{ml} \mathrm{C} 2 \mathrm{H} 5 \mathrm{OH})$. The determination of the overlay weld quality required the use of an Olympus SZX9 stereoscopic microscope (SM) in the dark field at magnification of up to 500x. The microstructure was observed using a Hitachi S-3400N scanning electron microscope (SEM) and the SE (SecondaryElectrons) as

Tab le 1. Selected parameters and their designation

\begin{tabular}{|c|c|c|c|c|c|}
\hline No. & Impulse current, A & Basic current, $\mathrm{A}$ & $\begin{array}{c}\text { Filler metal wire feeding rate, } \\
\mathrm{m} / \mathrm{min}\end{array}$ & $\begin{array}{c}\text { Number } \\
\text { of surfaced layers }\end{array}$ & $\begin{array}{c}\text { Overlay weld } \\
\text { designation on the tube }\end{array}$ \\
\hline 1 & 140 & 100 & 1.0 & 1 & $16 / 1$ \\
\hline 2 & 140 & 100 & 1.0 & 2 & $16 / 2$ \\
\hline 3 & 140 & 120 & 1.2 & 2 & $37 / 1$ \\
\hline 4 & 140 & 120 & 1.2 & 1 & $37 / 2$ \\
\hline 5 & 130 & 120 & 1.5 & 2 & $41 / 1$ \\
\hline 6 & 130 & 120 & 1.5 & 1 & $41 / 2$ \\
\hline 7 & 130 & 120 & 1.5 & 2 & $41 / \mathrm{W} / 1$ \\
\hline 8 & 130 & 120 & 1.5 & & $41 / \mathrm{W} / 2$ \\
\hline
\end{tabular}


well as the BSE observation techniques at magnification of up to 2000x.

The microanalysis of the chemical composition of the surfaced layers was performed using a Hitachi S-3400Nv scanning microscope provided with an energy dispersive spectrometer (EDS). The chemical composition tests were conducted using an accelerating voltage of $15 \mathrm{keV}$. The analysis of the chemical composition of the overlay welds was supplemented with the analysis of changes in the chemical composition on the line perpendicular to the overlay weld and the surface distribution of chemical elements in the fusion area.

\section{Test Results}

The calculated content of the base material in the overlay welds and the height of the overlay welds are presented in Table 2.

The macroscopic metallographic tests revealed that the content of the base material in the overlay weld could be reduced by using two-layer surfacing or by performing forced cooling inside the tube.

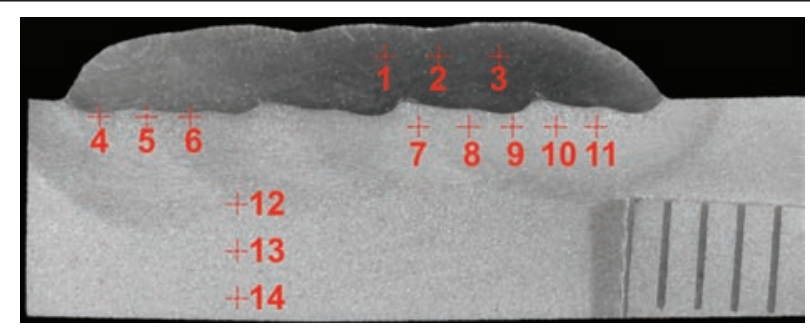

Fig. 1. Arrangement of hardness measurement points in the overlay weld and HAZ

The hardness tests were performed on the crosssection of the overlay welds in accordance with the scheme presented in Fig. 1. Selected results are presented in the graphic form in Fig. 2.

The chemical composition tests were performed on the overlay weld surface using spark source optical emission spectrometry. The tests aimed to determine the effect of surfacing conditions and parameters on the iron content of the overlay weld surface. The contents of selected chemical elements are presented in Table 3.

Ta b l e 2 . Overlay weld height $(W)$, fusion area $\left(F_{w}\right)$, overlay weld area $\left(F_{n}\right)$ and the calculated content of the base material in the overlay weld $\left(U_{p}\right)$

\begin{tabular}{|l|c|c|c|c|c|c|c|c|}
\hline $\begin{array}{c}\text { Overlay weld } \\
\text { geometry }\end{array}$ & Spec. 16/1 & Spec. 16/2 & Spec. 37/1 & Spec. 37/2 & Spec. 41/1 & Spec. 41/2 & Spec. 41/W/1 & Spec. 41/W/2 \\
\hline$U_{\mathrm{p}}, \%$ & 13.78 & 11.04 & 13.11 & 8.40 & 14.24 & 7.52 & 5.67 & 3.28 \\
\hline$F_{w}, \mathrm{~mm}^{2}$ & 160.6 & 182.9 & 120.6 & 154.3 & 165.5 & 150.1 & 143.3 & 132.7 \\
\hline$F_{n}, \mathrm{~mm}^{2}$ & 1004.7 & 1474.6 & 799.6 & 1681.7 & 995.1 & 1844.6 & 1735.5 & 1662.6 \\
\hline$H, \mathrm{~mm}$ & 2.52 & 3.64 & 2.11 & 3.84 & 2.81 & 4.21 & 2.12 & 2.66 \\
\hline
\end{tabular}

Ta b l e 3. Chemical composition of the overlay weld surface

\begin{tabular}{|c|c|c|c|c|c|c|c|c|}
\hline \multirow{2}{*}{$\begin{array}{c}\text { Chemical } \\
\text { composition, \% }\end{array}$} & \multicolumn{7}{|c|}{ Specimen designation } \\
\cline { 2 - 9 } & $16 / 1$ & $16 / 2$ & $37 / 1$ & $37 / 2$ & $41 / 1$ & $41 / 2$ & $41 / \mathrm{W} / 1$ & $41 / \mathrm{W} / 2$ \\
\hline $\mathrm{C}$ & 0.035 & 0.026 & 0.041 & 0.024 & 0.030 & 0.020 & 0.019 & 0.019 \\
\hline $\mathrm{Mn}$ & 0.167 & 0.073 & 0.236 & 0.056 & 0.143 & 0.033 & 0.088 & 0.08 \\
\hline $\mathrm{Cr}$ & 19.74 & 20.92 & 18.74 & 20.62 & 20.13 & 20.51 & 21.70 & 21.09 \\
\hline $\mathrm{Mo}$ & 8.020 & 8.401 & 7.399 & 8.181 & 7.975 & 7.988 & 6.871 & 8.248 \\
\hline $\mathrm{Fe}$ & $\mathbf{1 0 . 2 0}$ & $\mathbf{4 . 5 4 2}$ & $\mathbf{1 4 . 7 7}$ & $\mathbf{3 . 9 8}$ & $\mathbf{8 . 4 7 0}$ & $\mathbf{4 . 2 9 0}$ & $\mathbf{3 . 4 6 7}$ & $\mathbf{2 . 7 5 5}$ \\
\hline $\mathrm{Mg}$ & 0.0019 & 0.0017 & 0.0022 & 0.0020 & 0.0022 & 0.0023 & 0.0016 & 0.015 \\
\hline $\mathrm{Nb}$ & 3.434 & 3.577 & 3.228 & 3.722 & 3.383 & 3.620 & 0.045 & 3.438 \\
\hline $\mathrm{Ni}$ & 58.05 & 62.08 & 55.23 & 62.49 & 59.50 & 62.92 & 63.56 & 63.64 \\
\hline
\end{tabular}

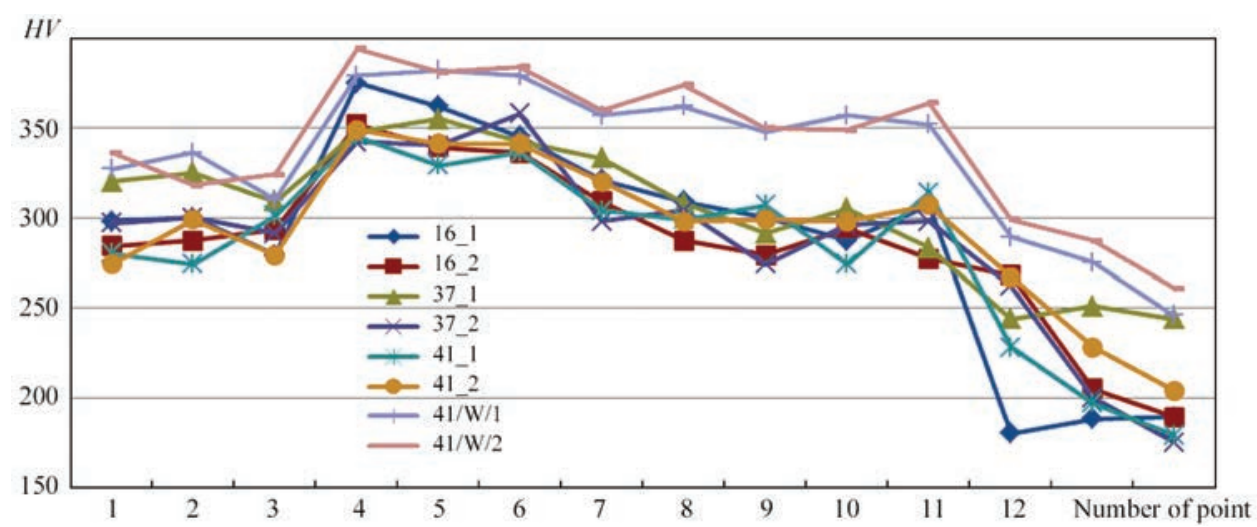

Fig. 2. Graphic representation of selected hardness measurement points on the cross-section of overlay welds 


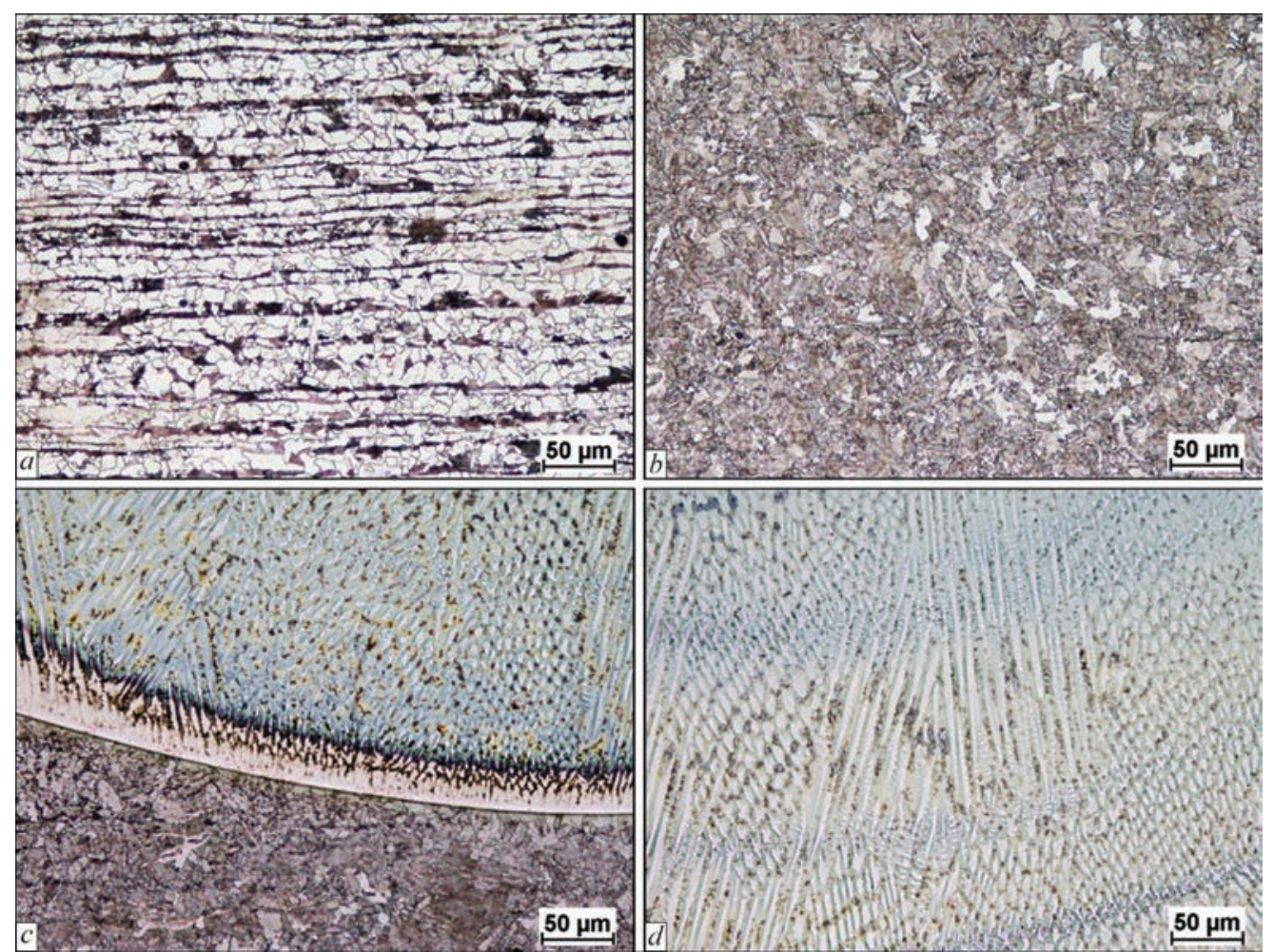

Fig. 3. Microstructure of the overlay weld (item 7 of Table 1) made of alloy Inconel 625 on the tube made of steel 13CrMo4-5; mag. $200 \mathrm{x}$

When analysing the chemical composition of the overlay weld metal it was ascertained that in terms of the two-layer overlay welds the content of iron on the overlay weld surface did not exceed $5 \%$ in each case. However, it should be noted that the necessity of making another, i.e. the second, overlay weld significantly extends the production process. In cases of the one-layer overlay welds, made without the forced cooling of the tube, in each case the content of iron on the overlay weld surface exceeded $5 \%$, often
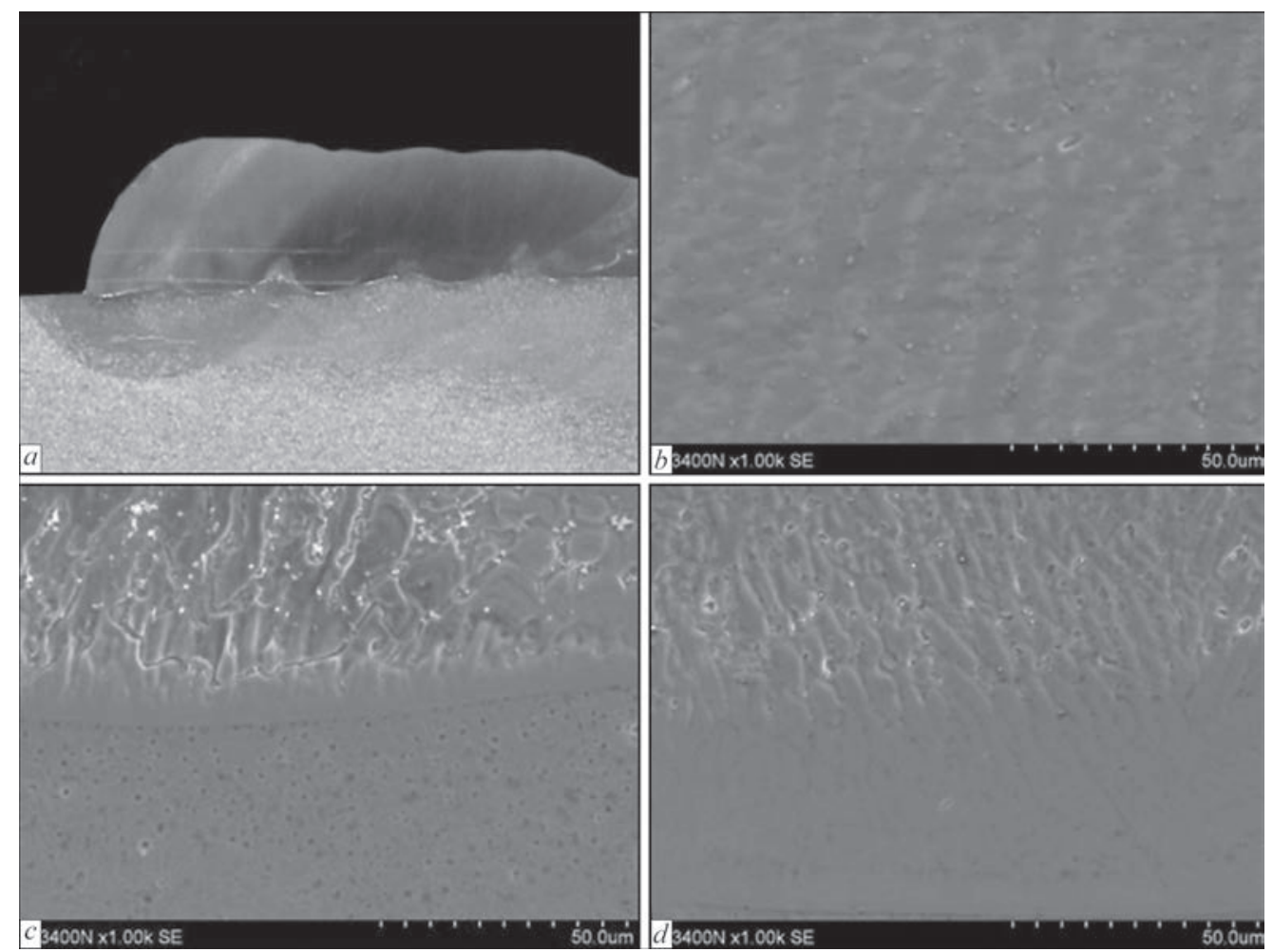

Fig. 4. Structure of the overlay weld made of alloy Inconel 625 on the tube made of steel 13CrMo4-5, specimen of item 7 of Table 1: a) overlay weld macrostructure (SM), b) overlay weld structure, SEM, SE; mag. 1000x; c) fusion line, SEM, SE; mag. 1000x, d) fusion line with the visible zone enriched in chromium SEM, SE; mag. 2000x 

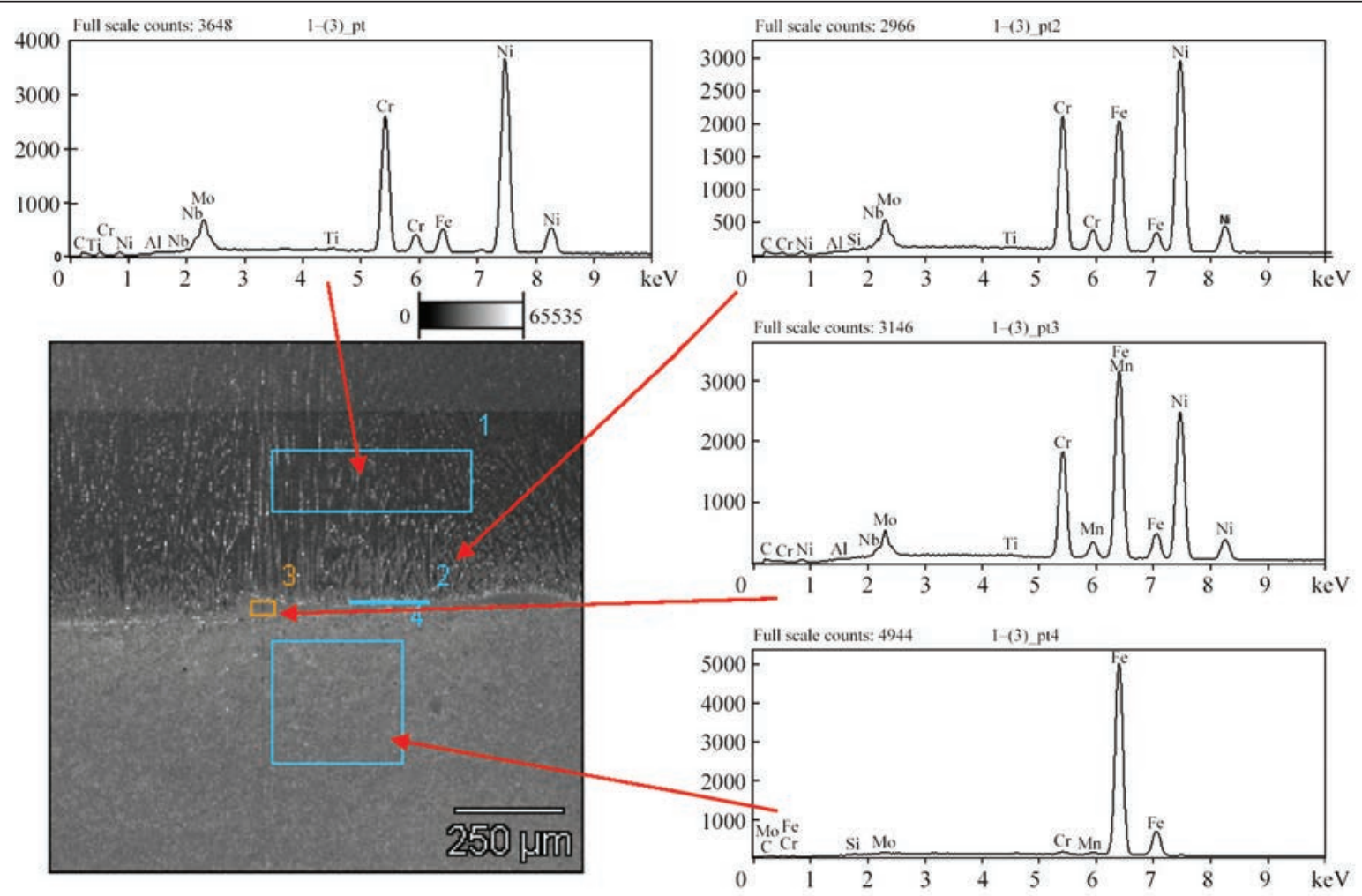

\begin{tabular}{|c|c|c|c|c|c|c|c|c|c|}
\hline Weight, \% & $A l-K$ & $S i-K$ & $T i-K$ & $C r-K$ & $M n-K$ & $F e-K$ & $N i-K$ & $N b-L$ & $M o-L$ \\
\hline $1-(3) p t 1$ & 0.1 & - & 0.2 & 22.4 & - & 5.1 & 62.2 & 3.3 & 6.6 \\
\hline 1-(3) pt2 & 0.1 & 0.1 & 0.1 & 17.2 & - & 23.7 & 52.1 & 1.2 & 5.5 \\
\hline 1-(3) $p t 3$ & 0.1 & - & 0.1 & 14.6 & 0.1 & 36.3 & 42.7 & 1.7 & 4.5 \\
\hline 1-(3) pt4 & - & 0.2 & - & 1.1 & 0.6 & 97.7 & - & - & 0.4 \\
\hline Atom $\%$ & $A l-K$ & $S i-K$ & $T i-K$ & $C r-K$ & $M n-K$ & $F e-K$ & $N i-K$ & $N b-L$ & $M o-L$ \\
\hline $1-(3) p t 1$ & 0.3 & - & 0.3 & 25.4 & - & 5.4 & 62.4 & 2.1 & 4.1 \\
\hline $1-(3) \quad p t 2$ & 0.2 & 0.2 & 0.1 & 19.2 & - & 24.6 & 51.6 & 0.8 & 3.3 \\
\hline $1-(3) p t 3$ & 0.2 & - & 0.1 & 16.2 & 0.2 & 37.6 & 42.0 & 1.0 & 2.7 \\
\hline 1-(3) pt4 & - & 0.5 & - & 1.1 & 0.6 & 97.5 & - & - & 0.2 \\
\hline
\end{tabular}

Fig. 5. Results of the chemical composition microanalysis (EDS) in the individual zones of the overlay weld; specimen of item 7 of Table 1

reaching $10 \%$. In cases of the one and two-layer overlay welds made on the tubes cooled inside using flowing water, the content of iron on the overlay weld surface amounted to $3.46 \%$ and $2.75 \%$, where the content of the base material in the overlay weld amounted to $5.67 \%$ and $3.24 \%$, respectively.
The microscopic metallographic tests were performed in the base material area, HAZ, fusion line and in the one-layer overlay weld made using parameters of item 7 in Table 1. The tests involved the use of light and scanning electron microscopy. Figure 3 presents photographs made using the light microscope, whereas Figure 4 presents the
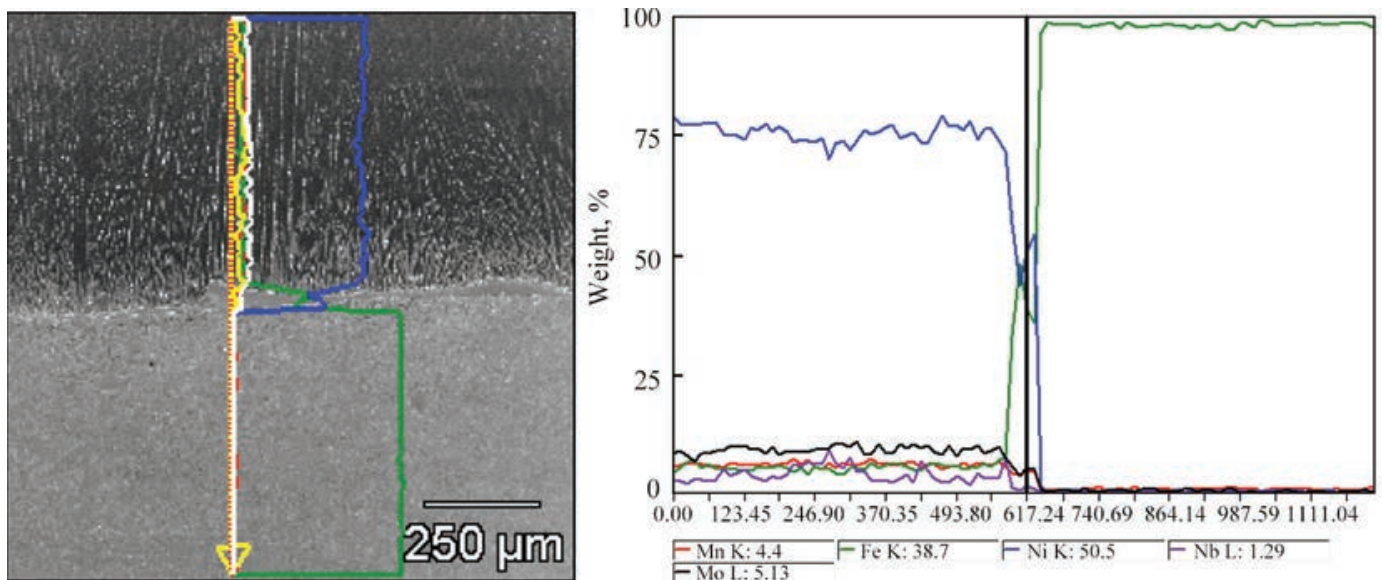

Fig. 6. Linear distribution of chemical elements in the overlay weld fusion line in specimen 41/W/1 (item 7, Table 1) 
microstructural photographs made using the scanning electron microscope. Figure 5 presents the results of the chemical composition microanalysis (EDS) in the individual zones, Figure 6 presents the linear distribution of chemical elements, whereas Figure 7 presents the surface distribution of chemical elements in the overlay weld fusion zone.

\section{Analysis of Test Results}

The tests aimed to determine the effect of TOPTIG surfacing conditions and parameters on the overlay weld geometry as well as on the content of the base material in the overlay weld and on the content of iron on the overlay weld surface. The tests also aimed at the identification of parameters, the use of which could ensure the obtainment of an iron content on the overlay weld surface not exceeding 5 $\%$. The initial technological tests performed on sheets enabled the identification of parameters ensuring the obtainment of overlay welds characterised by very high quality and the base material content in the overlay weld not exceeding $15 \%$. The above-named parameters are presented in Table 1.

The macroscopic metallographic test results and the calculations identifying the base material content in the overlay weld revealed that in cases of one-layer overlay welds designated 16/1,37/1 and 41/1 (items 1,3 and 5 of Table 1 ), the content of the base material in the overlay weld amounted to $13.78,13.11$ and $14.42 \%$ respectively, whereas the iron content on the surface of the overlay welds amounted to 10.2, 14.47 and $8.47 \mathrm{wt}$ \%, respectively, and in each case exceeded the allowed limit value of $5 \%$. In cases of the two-layer overlay welds, the base material content in the overlay weld in specimens designated $16 / 2,17 / 2$ and $41 / 2$ (items 2, 4 and 6 of Table 1) amounted to $11.04,8.4$ and $7,52 \%$, respectively, whereas the iron content on the surface of the overlay welds amounted to 4.54, 3.98 and 4.29wt. $\%$, respectively. As can be seen above, in each case the condition limiting the allowed iron content in the overlay weld to $5 \%$ was satisfied. However, it should be noted that the time required to make two-run overlay welds was unacceptable in terms of industrial applications. In addition, the reduction of the base material content in the overlay weld was obtained by increasing the volume of the filler metal, which, in turn, significantly increased the cost of surfacing. The foregoing inspired an attempted reduction of the degree of stirring of the overlay weld metal with the base material by using the forced cooling of the tube with water flowing during the process of surfacing. The subsequent tests involved the making of two overlay welds designated as $41 / 1$ and $41 / 2$ (items 7 and 8 of Table 1) subjected to macroscopic metallographic tests, measurements determining the base material content in the overlay weld and measurements of the chemical composition of the overlay weld surface. The base material content in the two overlay (one and two-layer) welds amounted to 5.67 and $3.28 \%$, respectively. It was possible to obtain a very shallow penetration depth (below $0.3 \mathrm{~mm}$ ), which, in turn, enabled the obtainment of a very low stirring degree. The analysis of the chemical composition of the overlay weld revealed that the iron content amounted to 3.47 and $2.75 \mathrm{wt}$. $\%$, i.e. considerably below the required criterion. The changes in the base material content in the overlay weld and the corresponding changes in the iron content on the overlay weld surface in relation to surfacing process conditions and parameters are presented below in Figure 8.

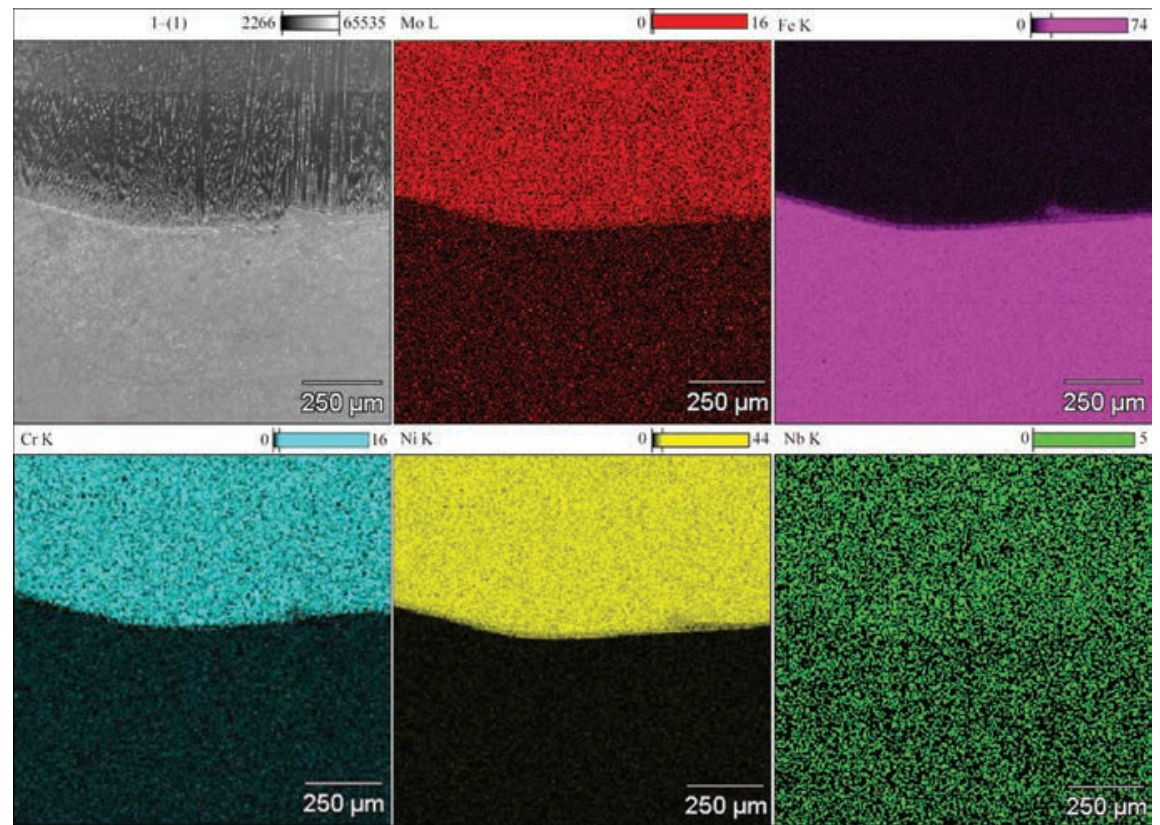

Fig. 7. Surface distribution of chemical elements in the overlay weld fusion zone, specimen no. 41/W/1 (item 7, Table 1) 
The hardness tests revealed that the hardness in the overlay weld metal amounted to approximately $274 \ldots 336 H V 10$, where the highest value was obtained in the overlay welds made using the forced cooling of the tube $(310 \ldots 336 H V 10)$. Such a high value could be attributed to the fast cooling of the overlay weld metal as well as the related deformation of the tube resulting in its (strain) hardening. Depending on an overlay weld subjected to a test, the HAZ hardness amounted to approximately 329...394 $H V 10$, where the highest value was obtained in the overlay welds made using the forced cooling of the tube and was restricted within the range of $379 \ldots 394 H V 10$, i.e. on the boundary of the allowed hardness amounting to $380 H V 10$ according to the requirements of EN ISO 15614-7 specifying the conditions of welding procedure qualification. The above-named increased hardness in the HAZ can be ascribed to the accelerated cooling of the area.

The microscopic metallographic tests revealed that the base material of the tube made of steel $13 \mathrm{CrMo} 4$ was the ferritic-pearlitic structure, typical of the aforesaid steel grade. In turn, in the heat affected zone adjacent to the fusion line, the intense thermal cycle accompanying the process of surfacing delayed the martensitic transformation. The structure of the above-named area was composed of martensite and bainite, responsible for the significant increase in hardness. The overlay weld microstructure in the fusion line contained a layer of entirely different colour than that of the remaining overlay weld area. The composition of the above-named area was identified in further tests involving the use of electron microscopy. In turn, the overlay weld consisted of the dendritic austenitic structure, typical of alloy Inconel 625 , building up orthogonally towards the surface of the material subjected to surfacing.

The tests performed using electron microscopy revealed that the differently coloured layer (i.e. differing from the colour of the overlay weld metal) observed in the fusion line using the metallographic tests contained $17 \% \mathrm{Cr}, 23 \% \mathrm{Fe}, 52 \% \mathrm{Ni}, 1.5 \%$ $\mathrm{Nb}$ and $5.5 \%$ Mo. The analysis of the chemical composition of the overlay weld surface revealed the following contents of chemical elements: $63.64 \% \mathrm{Ni}$, $21.09 \% \mathrm{Cr}, 8.25 \% \mathrm{Mo}, 3.44 \% \mathrm{Nb}$ and $2.75 \% \mathrm{Fe}$. As can be seen, the key criterion requiring that the iron content on the overlay weld surface be below $5 \%$ was satisfied again. The analysis of the chemical composition of the overlay weld at the half of its thickness revealed that the contents of the primary chemical elements amounted to $60.4 \% \mathrm{Ni}, 21.4 \%$ $\mathrm{Cr}, 6.6 \% \mathrm{Mo}, 3.0 \% \mathrm{Nb}$ and $8.2 \% \mathrm{Fe}$ and changed towards the base material to reach $39.9 \% \mathrm{Ni}, 13.2 \%$ $\mathrm{Cr}, 4.1 \% \mathrm{Mo}, 1.6 \% \mathrm{Nb}$ and approximately $40.9 \% \mathrm{Fe}$ in the fusion line.

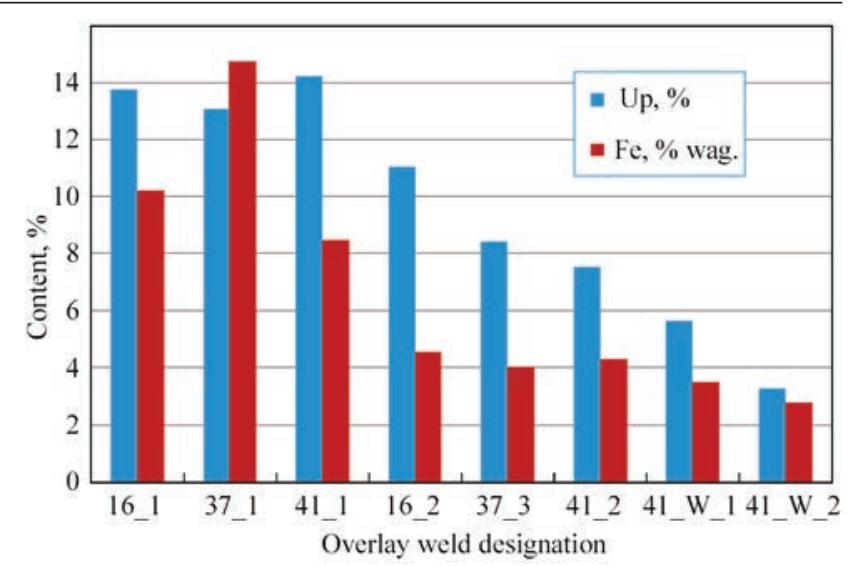

Fig. 8. Base material content in the overlay welds (Up) and the iron content $(\mathrm{Fe})$ on the overlay weld surface

\section{Conclusions}

1. The TOPTIG technology enables the making of overlay welds characterised by very high quality and the minimum dilution of the overlay metal with the base material (at least $3.28 \%$ ) as well as the obtainment of the iron content on the overlay weld surface amounting to $2.75 \%$ (if the forced cooling of the base material is used). Surfacing without cooling leads to a significantly higher base material content in the overlay weld (approximately $14 \%$ ), where the metal content on the overlay weld surface amounts to $8.47 \%$.

2. Single-sided surfacing without forced cooling does not enable the making of an overlay weld using alloy Inconel 625, characterised by an iron content of below $5 \%$ on the overlay weld surface.

3. Single-sided surfacing with forced cooling favours the formation of the martensitic structure in the HAZ area and the obtainment of high hardness $(>380 \mathrm{HV})$ values because of the cooling (inside the tube) involving the use of flowing water. However, the above-named technological aspect is necessary to satisfy the criterion of the maximum iron content on the overlay weld surface amounting to $5 \%$.

\section{References}

1. Rozmus-Górnikowska M. (2014) Badania mikrostruktury i mikrosegregacji składu chemicznego warstw ze stopu Inconel 625 napawanych techniką CMT na podłoże ze stali $16 \mathrm{Mo}_{3}$. Przeglad Spawalnictwa., 12, 4-8.

2. Rutzinger B. (2012) Kierunki rozwoju w przemyśle energetycznym. Zastosowanie napawania metodą CMT w elektrowniach węglowych. Biuletyn Instytutu Spawalnictwa, 5, 63-66.

3. Rutzinger B. (2014) Wpływ procesu napawania na stopień wymieszania napoiny wykonanej spoiwem ERNiCrMo-3 (stop typu 625) na podłożu ze stali niestopowej. Ibid., 5, 72-74.

4. Adamiec P., Adamiec J. (2006) Aspekty napawania stopami Inconel 625 i 686 elementów w kotłach do spalania odpadów. Przeglad Spawalnictwa, 5-6, 11-14.

5. Nowacki J., Wypych A. (2010) Mikrostruktura i odporność na wysokotemperaturowe utlenianie napoin nadstopu Inconel 625 na stali niskostopowej. Biuletyn Instytutu Spawalnictwa, 5, 84-87. 
6. Jarosiński J., Błaszczyk M., Tasak E. (2007) Napawanie stali stosowanych w energetyce stopami na osnowie niklu. Przeglad Spawalnictwa, 1, 30-33.

7. Jarosiński J., Błaszczyk M. (2006) Napawanie stali stosowanych $\mathrm{w}$ energetyce stopami na osnowie niklu. Problem praktycznego pomiaru zawartości żelaza. Spajanie, 2, 18-23.

8. Abioye T.E., McCartney D.G., Clare A.T. (2015) Laser cladding of Inconel 625 wire for corrosion protection. Journal of Materials Processing Technology, 217, 232-240.

9. Abioye T.E., Folkes J., Clare A.T. (2013) A parametric study of Inconel 625 wire laser deposition. Journal of Materials Processing Technology, 213, 2145-2151.

10. Pfeifer T., Winiowski A. (2014) Badania procesu napawania i spawania plazmowego oraz badanie procesów dyfuzyjnego lutowania i lutospawania połączeń różnoimiennych metali lekkich. Praca badawcza Instytutu Spawalnictwa no. Cf-93 (ST-333).

11. Pfeifer T. (2015) Opracowanie technologii napawania plazmowego proszkiem o składzie stopu Inconel 625. Praca badawcza Instytutu Spawalnictwa no. Cf-94.

12. Гладкий П. В., Переплетчиков Е. Ф., Рябцев И. А. (2007) Плазменная наплавка. Киев: Екотехнология.

13. Рябцев И. А., Сенченков И. К., Турык Э. В. (2015) Haплавка. Материаль, технологии, математическое моделирование. г. Гливице, Польша, Изд-во Силезского политехнического института.

Т. Пфайфер ${ }^{1}$, М. Ружанскі ${ }^{1}$, В. Гробош ${ }^{1}$, Я. Рикала ${ }^{1}$, І. О. Рябцев ${ }^{2}$

${ }^{1}$ Інститут зварювання, Польща, 44-100,

м. Глівіце, вул. Б. Чеслава, 16-18. E-mail: is@is.gliwice.pl

${ }^{2} \mathrm{IE}$ ім. Є. О. Патона НАН України.

03680, м. Київ-150, вул. Казимира Малевича, 11.

E-mail: office@paton.kiev.ua

ТЕХНОЛОГІЧНІ АСПЕКТИ РОБОТИЗОВАНОГО ТОРТІG НАПЛАВЛЕННЯ КОТЕЛЬНИХ СТАЛЕВИХ ТРУБ З ВИКОРИСТАННЯМ СПЛАВУ INCONEL 625

Метою дослідження $\epsilon$ розробка технологічних параметрів процесу TOPTIG наплавлення (з використанням сплавy INCONEL 625) труб котлів (45x5), виготовлених зі сталі 13CrMo4-5, які гарантують вміст заліза в поверхневому шарі шва нижче 5 \%. Було визначено, що технологія TOPTIG дозволяє виконувати наплавочні шви, які характеризуються дуже високою якістю і мінімальним рівнем перемішування 3 основним металом (вміст заліза становить 2,75\% в поверхневому шарі шва за допомогою примусового охолодження). Наплавлення без охолодження призводить до набагато більшого змісту основного металу в шві (приблизно 14\%), а вміст заліза в поверхневому шарі шва досягає $8,47 \%$.

Ключові слова: роботизована наплавка, метод TOPTIG, сплав Inconel 625, котельні труби, котли для спалювання відходів, вміст заліза на поверхні шва

Т. Пфайфер ${ }^{1}$, М. Ружански ${ }^{1}$, В. Гробош ${ }^{1}$, Я. Рыкала' ${ }^{1}$ И. А. Рябцев²

${ }^{1}$ Институт сварки, Польша, 44-100, м. Гливице, ул. Б. Чеслава, 16-18. E-mail: is@is.gliwice.pl ${ }^{2}$ ИЭС им. Е. О. Патона НАН Украины. 03680, г. Киев-150, ул. Казимира Малевича, 11. E-mail: office@paton.kiev.ua

ТЕХНОЛОГИЧЕСКИЕ АСПЕКТЫ РОБОТИЗИРОВАННОЙ ТОРТІG НАПЛАВКИ КОТЕЛЬНЫХ СТАЛЬНЫХ ТРУБ С ИСПОЛЬЗОВАНИЕМ СПЛАВА INCONEL 625

Целью исследования является разработка технологических параметров процесса TOPTIG наплавки (с использованием сплава Inconel 625) труб котлов (45х5), изготовленных из стали 13CrMo4-5, которые гарантируют содержание железа в поверхностном слое шва ниже $5 \%$. Было определено, что технология TOPTIG позволяет выполнять наплавочные швы, которые характеризуются очень высоким качеством и минимальным уровнем перемешивания с основным металлом (содержание железа составляет 2,75 \% в поверхностном слое шва с помощью принудительного охлаждения). Наплавка без охлаждения приводит к гораздо большему содержанию основного металла в шве (примерно 14 \%), а содержание железа в поверхностном слое шва достигает $8,47 \%$.

Ключевые слова: роботизированная наплавка, метод TOPTIG, сплав Inconel 625, котельные трубы, котлы для сжигания отходов, содержание железа на поверхности шва

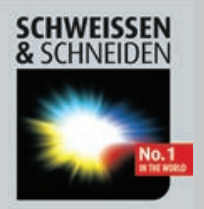

\section{Международная выставка по сварке и резке SCHWEISSEN \& SCHNEIDEN 2017}

Тематические разделы выставки:

- оборудование и технологии для всех видов сварки, наплавки и пайки;

- оборудование и технологии для термической обработки;

- материалы для сварки, резки, наплавки, напыления, пайки;

- средства защиты, технологии безопасности;

- контроль качества;

- инструменты;

- научные разработки в области сварки. 